\title{
The Impacts of Climate Change on Nigerian Ecosystems: A Review
}

\author{
Ikumbur B. ${ }^{*}$ and Iornumbe S. \\ Department of Geology, Benue State Polytechnic Ugbokolo, Nigeria \\ Corresponding Author: *ibemsen@gmail.com
}

https://doi.org/10.36263/nijest.2019.02.0128

\begin{abstract}
Climate change is the single biggest environmental issue facing the world today. It has become a great challenge to our generation and its impact is felt in almost every society in the world. Nigeria is one of the most vulnerable countries in Africa. Nigeria as a developing nation with a population of about 200 million people is likely to be adversely impacted by climate change due to its vulnerability and low coping capabilities. Climate change is evidently linked to human actions, and in particular from the burning of fossil fuels and changes in global patterns of land use. The impacts of human activities, as well as those of natural phenomena on global warming, climate change, and the environment, were presented and discussed. Various manifestations of its impact are evident in Nigeria, which includes temperature rise, increase in draught, and scarcity of food instigated by irregularities in rainfall, over flooding, and so on. This paper examines the concepts of global warming and climate change; its impact on the Nigeria ecosystems. It highlights the climate change-related risks and hazards the nation could face if best practices are not employed to prevent and mitigate its impact. Two sets of measures have been advocated for confronting climate change, these are mitigation and adaptation measures. The review explores possible adaptation strategies that are required to respond to the climatic variations and suggests ways that these adaptation strategies can be implemented.
\end{abstract}

Keywords: Climate change, Impact, ecosystems, global warming, mitigation, adaptation, greenhouse effects

\subsection{Introduction}

An ecosystem is a community of living organisms in conjunction with non-living components of their environment, interacting as a system (an entity). These biotic and abiotic components are linked together through nutrient cycles and energy flows. Climate change refers to an increase in mean (average) temperatures. Human activities and natural variations are believed to be contributing factors to an increase in mean global temperatures. The increase in average global temperatures is caused primarily by an increase in greenhouse gases such as Carbon Monoxide, Carbon dioxide, Water vapour, Methane, Nitrous Oxide, and Ozone. There is a new damaging greenhouse gas that has been discovered called Sulfuryl Fluoride. It was first used as a fumigant to kill termites. This chemical can last for up to 40 years and traps significant amounts of heat more than Carbon dioxide (Reigart and Roberts, 2013).

Human lives are directly linked to the climate. Climate change of course has great impact on the ecosystems. There has been a continuous rise in global temperature in the last 130 years, which has huge consequences on a wide-range of climate related factors. It is evident that carbon dioxide $\left(\mathrm{CO}_{2}\right)$ and Methane are being dumped in the atmosphere at an alarming rate as a result of the advent of industrial revolution (Nwankwoala, 2015). There are oil spillage and gas flaring all over the environment. Fossil fuels burning and deforestation which produce greenhouse gases are on the increase. This phenomenon is called greenhouse effect. Greenhouse gases act like blanket around the earth, wrapping energy into the atmosphere. This is the cause of the earth warming. As such our 
earth's average temperature has risen by $1^{0} \mathrm{C}$ over the past century, and is projected to raise another $1.1^{\circ} \mathrm{C}$ to $6.4^{\circ} \mathrm{C}$ over the next hundred years (Nwankwoala, 2015). This rise in temperature of the planet can bring about ice caps melting, sea levels rising and other environmental challenges. The build-up of greenhouse gases can change Earth's climate and result in dangerous effects to human health, safety, welfare and to the ecosystems. There are distortions and pollutions in our water supplies, agriculture, weather, seasons, power, transportation system, and so on. However, it is important to state that, some changes in the climate are unavoidable; carbon dioxide can stay in the atmosphere for nearly a century. As such, the earth will continue warming, and the warmer it becomes, the greater the risk for more adverse changes to the climate and the Earth's system. Even though it is difficult to predict or forecast the impact of climate change, yet, what is certain is that the climate we are used to is no longer a reliable guide for what to expect in future. In view of the adverse effects of certain human activities, that cause earth warming and climate change, it is important that we begin to make choices that will reduce greenhouse gas pollution, and the best way out of this is to get ourselves and the younger generations educated through our education systems and other avenues of public enlightenment (Nwankwoala, 2015).

Global warming is causing the glaciers and arctic ice cap that has been preserved for millions of years to melt faster, and this can affect many different ecosystems. The flow of colder water from the melting ice is flowing into the sea much faster, and this can cool the warm water flows that are necessary for tropical marine life. Tropical fish and animals may not be able to survive if the water temperature changes drastically and marine life that can absorb may do so increasingly and become threatened. The Pristine lands and habits that are around the melting ice can also be adversely affected. Greenhouse gases pose a very real and significant threat to the world ecosystems. Greenhouse gases are gases present in the atmosphere that have a greenhouse effect, trapping heat in the atmosphere and close to the surface of the earth rather than allowing the heat to go back into space. Emissions of greenhouse gases can be as a result of burning fossil fuels, and also of the pollution of the air from many different chemicals. This causes the air in the atmosphere to stay warmer and can have a devastating effect on all the ecosystems of the world (Nwafor, 2007; IPCC, 2007; Odjugo, 2009).

Global warming due to increased greenhouse gases has already had a great impact on the earth and many of the ecosystems. The weather around the world is slowly warming, and tropical storms, devastating hurricanes, typhoons, and other severe weather patterns are on the increase. The climate and temperature of areas are changing, leading to an increase in unknown and unusual bacteria and viruses to be found. This can pose a very serious problem since this can lead to a global threat that is worldwide from climate-related diseases and other life-threatening challenges (UNFCC, 2006; FAO, 2008; Hans-Peter et al., 2009; Osman-Elasha, 2010; Raheem, 2011; UNDP, 2013). As global warming from greenhouse gases affects the world ecosystems, the ocean is one of those affected greatly. Tropical storms and hurricanes, as well as some other weather-related events depend on the warm water. Warmer water means an increase in tropical storms and worse, both in intensity and frequency. Hurricanes and tropical storms need warm water to derive their energy from, and global warming is providing this. In the last ten years, storms that are more powerful have been occurring frequently, and if greenhouse gases continue to contribute to global warming it will only get worse because of the great damage done to the world ecosystems (UNFCC, 2007).

It is crucial that we try and slow down or completely eliminate the emission of greenhouse gases so that there is no longer a threat to the world ecosystems from them. This means lowering and/or stopping our dependence on fossil fuels because these gases are mostly responsible for the greenhouse gases that are damaging the world ecosystems (UNFCC, 2007). Using alternative and renewable fuel sources instead of fossil fuels is the way to prevent global warming from becoming worse. By controlling and reducing the greenhouse gases that are released, by minimizing the use of fuels that contribute to the emission of these gases, we can help preserve the world ecosystems and prevent them from suffering more damage. This can be done by using biofuels and alternative energy sources (such as solar energy, geothermal energy, wind energy, hydropower energy, biomass energy and energy from waste) whenever possible instead of using fossil fuels (UNDP, 2013). This will keep the 
world ecosystems in good shape and prevent the emissions of large amounts of greenhouse gases. The renewable energy world is a safer world to live in since it does not have a harmful nature.

Climate change impacts ecosystems, livelihoods, human security and socio-economic development of societies, and has been defining the direction of human wellbeing and development (UNDP, 2008). The world, especially the developing nations will be faced with shortages of necessities of life such as water and food. Climate change affects health, shelter, livelihood, and life in general. The negative impacts of climate change currently reflect on dwindling natural resources, including food, which generally affects the human environment, economy, and health (Onyenechere, 2010). Oladipo (1995) noted that as the planet gets warmer, the pattern of rainfall alters, extreme weather events such as floods, droughts, and forest fires turn out to be recurrent. The world ecosystems, economy, and a healthy environment are at the mercy of variations of the earth's climate, which is moving at a pace that seems beyond recovery (Olusola, 2012).

Researches have shown that Nigeria is already being plagued with diverse ecological problems, which have been directly linked to the on-going climate change (Odjugo 2001a; 2005; Odjugo and Ikhuoria 2003; NEST 2003; Chindu and Nyelong 2005; Mshelia 2005; Ayuba et al., 2007). While Odjugo (2001a, 2005) observes erratic pattern of weather elements in Nigeria, Odjugo and Ikhuoria (2003) show that climate change has started impacting on desertification and Ayuba et al., (2007) show that climate change is impacting negatively on plant species composition in North-eastern Nigeria. These may not be the only impacts of climate change in Nigeria. It is on this premise that this study took an overview of the impacts of climate change in Nigeria with the aim of compiling and synthesizing them holistically. Africa is already a continent under pressure from climate-related stresses and is highly vulnerable to the impact of climate (Jagtap, 2007; Nwafor, 2007). Available evidence suggests that the negative impact of climate change on our world today is prominent in Africa (Jagtap, 2007; Nwafor, 2007). Given that most dry lands in Africa are poverty hot spots as well, the risk of desertification is high in many of these areas and the poor Africans have inevitably become both the victims and willing agents of environmental damage and desertification (Adefalolu, D., 2007). In SubSaharan Africa, persistent drought and desertification have been the order in recent times, which may likely persist (Onyenechere, 2010).

Nigeria is experiencing adverse climatic conditions with negative impacts on the welfare of millions of people. Persistent droughts and over flooding, off-season rains and dry spells have sent growing seasons out of orbit, on a country dependent on rain-fed agriculture. There is an indication of the possible danger with lakes drying up and a reduction in river flow in arid and semi-arid regions. The possible result is inadequate water supplies for use in agriculture, hydropower generation and other users. The main suspect for all these havoc is climate change. Scientific studies show that snows are disappearing rapidly (UNFCC, 2006). Climate change has been confirmed following the release of the $5^{\text {th }}$ IPCC Assessment Report (IPCC, 2014). Human influence on the climate system is clear, and recent anthropogenic emissions of greenhouse gases are the highest in history. Recent climate changes have had widespread impacts on human and natural systems (IPCC, 2014). Warming of the climate system is unequivocal, and since the 1950s, many of the observed changes are unprecedented over decades to millennia. The atmosphere and ocean have warmed, the amounts of snow and ice have diminished, and sea level has risen (IPCC, 2014).

Africa will be worst hit by the effects of climate change which Nigeria is part of (Olaniyi et al., 2014).In Nigeria, the increase in drought, scarcity of food caused by irregular rainfall, over flooding, to mention but a few, are all evidence of the impact of climate change in the country. Vulnerable communities like the coastal and delta regions are largely suffering the consequences such as over flooding leading to a drift of many individuals in the Niger Delta region (Olmos, 2001). Atilola, (2012) notes that "while the industrialized countries of the world, the major contributors to climate change have the capacity to respond to the impact of climate change, most developing countries do not have adaptive capacity to global warming". Watson, et al., 1998) argued that the "vulnerability of a region depends to a great extent on its wealth, and the poverty limits adaptive capabilities". 
This paper discusses the issue of global warming and climate change; its impact on the ecosystems in Nigeria. It highlights the climate change-related risks and hazards the nation could face if best practices are not employed to prevent and mitigate its impact. It explores possible adaptation strategies that are required to respond to the climatic variations and suggests ways that these adaptation strategies can be implemented.

\subsection{Concepts of Climate Change}

\subsection{Greenhouse effect}

This is simply the process by which radiative energy leaving the earth's surface is absorbed by some atmospheric gases, called greenhouse gases. Some examples of these greenhouse gases are carbon monoxide, carbon dioxide, methane, nitrous oxide, fluorinated gases, and chlorofluorocarbons. Carbon dioxide is the most common of greenhouse gases but there are greenhouse gases that are more potent than carbon dioxide. The methane gas is estimated to be 21 times more potent than carbon dioxide with an atmospheric lifespan of about 12 years (EPA, 2009a). The nitrous oxide is 310 times more potent as a greenhouse gas than carbon dioxide and has an atmospheric lifespan of 120 years (EPA, 2009b). It is also worthy to note that methane and carbon dioxide are emitted largely during the burning of fossil fuels, and nitrous oxide is produced during agricultural activities, as well as the burning of solid waste; while fluorinated gases are mostly obtained from industrial activities. OECD (2008) notes that quantitatively, the largest share is accounted for by power generation (electricity production and transmission were responsible for $26 \%$ of global emissions in 2004), followed by industry, generally (about 19\%) and transportation (13\%). It is important to note that deforestation and forest degradation (about 17\%) are estimated to account for more emissions globally than the entire transport sector. More so, it is the increasing temperature of the globe that culminates into other changes around the world, such as strong winds (hurricanes), melting glaciers, and the loss of biodiversity. This process makes the temperature rise in the atmosphere just as it does in the artificial greenhouse, and is called global warming (Ayuba et al., 2007). It is now clear that global warming is mostly due to man-made emissions of greenhouse gases (mostly $\mathrm{CO}_{2}$ ).

\subsection{Global warming}

Global warming is "the increase in the average temperature of the earth's near-surface air and the oceans since the mid-twentieth century and its projected continuation". The scientific community has reached a consensus that global warming is real and that human activities are causing the warming trend. Global temperatures have steadily risen over the last century, and according to scientists, 2005 was the warmest year on record and the warming trend is expected to continue through the $21^{\text {st }}$ century and beyond (Olaniyi et al., 2014). From various scientific researches, it has been estimated that average global temperatures of the earth surface increased $0.74^{\circ} \mathrm{C} \pm 0.18^{\circ} \mathrm{C}$ during the 100 years ending in 2005 (Olaniyi et al., 2014). Scientific climate modelling projections recently summarized by the Intergovernmental Panel on climate change (IPCC) indicate that global surface temperature will likely rise a further $1.1^{\circ} \mathrm{C}$ to $6.4^{\circ} \mathrm{C}$ during the $21^{\text {st }}$ century (IPCC, 2007); while Nebedum and Nnaemeka, (2016) estimated an average rise in temperature ranging from $1.5^{\circ} \mathrm{C}$ to $4.5^{\circ} \mathrm{C}$ on the earth if the greenhouse gas emissions continue through 2030. Climate is the average state of the weather; it is fairly stable and predictable, while the weather is the day to day state of the atmosphere; it is a chaotic non-linear dynamic system (Olaniyi et al., 2014). In general terms, climate means the pattern of weather which involves averages of variables such as cold and hot, drizzles and rain, cloudy and clear, breeze and blizzard, humid and dry, and other variables that can be measured at any time. The major effect of global warming is climate change, which is the sudden change of climate patterns and the resultant effects on the environment and human life. Climate change is the change in the state of the climate that can be identified by changes in day to day state of the atmospheric properties which persists for very long periods. Climate change occurs when the amount of energy stored by the "climate system" is varied (Olaniyi, et al., 2014). The variation takes place when the balance between 
energy received from the sun and the radiated energy is disturbed. The disturbance can be caused by several natural systems like changes in earth's composition, variation in earth's orbit, variation in ocean circulation, and changes in sea level. In recent times, human activities are the cause of the disturbance (Olaniyi et al., 2014).

\subsection{Climate change}

Climate change simply refers to the climatic condition of a place after a given period of time. These include temperature, humidity, precipitation, and wind. Natural events and human activities are believed to be contributing to an increase in average global temperature (Anyadike, 2009). The reasons for climate change may be natural; however, it is mainly caused by human activities. Human activities often lead to the release of greenhouse gases into the air which has the ability to easily retain excessive heat in the earth space. Activities that involve the burning of fossil fuels, including transportation and energy production, are increasing the concentrations of greenhouse gases in the atmosphere, trapping heat and causing global warming (Ayuba et al., 2007). Ogbo and Onyedinma, (2012) noted that "The extra-terrestrial factors include solar radiation (quantity and quality), while the anthropogenic factors involve human activities that either emit large amounts of greenhouse gases into the atmosphere that depletes the ozone layer or activities that reduces the amount of carbon absorbed from the atmosphere". The reaction of some greenhouse gases with rainwater produces acid rain during fossil fuel combustion and this contributes to climate change. Greenhouse gases cause the greenhouse effect, which is the reduction of the amount of infrared radiation emitted by the earth surface which escapes to outer space by these gases (Uyigue, et al., 2010).

\subsection{Vulnerability}

The IPCC (2001) defines vulnerability as "the degree to which a system is susceptible, or unable to cope with adverse effects of climate change, including climate variability and extremes". The vulnerability could mean the potential of a population to be negatively affected by the impact of climate change, whether small or high intensity. Nigeria, like every other developing nation, faces the risk of the impacts of climate change. This risk, directly or indirectly, will be detrimental to the nation's economy if it is not effectively addressed. The vulnerability of a group can be affected by features that are both socioeconomic and physical. Among the populations that are particularly vulnerable to climate-shocks are those living in particularly dangerous locations, such as those living in floodplains, settlements that lack protective infrastructure and poor quality housing (Satterthwaite et al., 2007). It is worthy to note that vulnerable groups differ in the magnitude of climate change impacts on their general wellbeing and adaptive abilities, such as health condition, age, income, knowledge, and resources. It has been noted that households that have meaningful access to economic resources and maintain effective social networks tend to be less vulnerable but can experience a larger share of losses (in absolute terms) than households with meagre resources and poor social networks. The more affluent households tend to be more resilient and more likely to recover quickly from climate-related stress and stimulus than the poorer ones (Blaiki et al., 1994; Wisner et al., 2003; Fatile et al., 2012). Similarly, vulnerability varies across regions, continents, and countries. This can be noticed in the uneven distribution of rainfall and temperature, as well as resources. Though vulnerability differs substantially across regions, it is also recognized that even within regions, degrees of vulnerability vary (IPCC, 2001).

\subsection{Causes and Evidence of Climate Change in Nigeria}

\subsection{Causes of climate change}

Climate change is caused by two basic factors which include natural processes (bio-geographical) and human activities (also known as anthropogenic factors). The earth's climate can be affected by natural 
factors that are external to the climate system such as changes in volcanic activity, solar radiation and earth's orbit around the sun; these factors and its effects have relatively short term effects on climate (Nebedum and Nnaemeka, 2016). Climate change is caused by a change in global energy balance owing to fluctuations in the earth's orbit, ocean circulation, and atmospheric composition (Olaniyi, et al., 2014). The United Nations Framework on Climate Change (UNFCC) uses the term "Climate Change" only for human induced change, while the term "Climate Variability" applied for changes due to external forcing. External forcing is climate change caused by change in the global energy balance owing to fluctuations in the earth's orbit, ocean circulation and atmospheric composition (Olaniyi et al., 2014)

The anthropogenic factors which are human activities that emit large amount of greenhouse gases into the atmosphere that depletes the ozone layer or activities that reduce the amount of carbon absorbed from the atmosphere. Human activities such as burning of fossil fuels, gas flaring, urbanization, agriculture (fertilizer application, fermentation among others), cement production and changes in land use like deforestation and desertification release greenhouse gases (GHGs) into the atmosphere which increase the already existing concentration of these gases. The human factors have been proven to be responsible for the ongoing unequivocal climate change or global warming (IPCC, 2007; IPCC, 2014).

Industrial activities are other causes of climate change. For example, the activities of automobiles and other industries have led to the emission of several gases like carbon dioxide into the atmosphere which over time affects the composition of greenhouse gases leading to altered climate (Kadafa, 2012).

According to the South African Confederation of Agricultural Union, the main greenhouse gases are carbon dioxide, methane and nitrous oxide which accounts for $80 \%, 14 \%$ and $6 \%$ of the total greenhouse gas emissions respectively (South African Confederation of Agricultural Union, SACAU, 2009). Greenhouse gases are good absorbers of heat radiation coming from the earth surface and acting like a blanket over the atmosphere keeping it warmer than it would be. It has been suggested that if the current trends of anthropogenic greenhouse gas emissions continue to 2030, the earth is likely to experience an average rise in temperature ranging from $1.5^{\circ} \mathrm{C}$ to $4.5^{\circ} \mathrm{C}$ (Porter and Brown, 1991). It is well established that the activities of developed nations are mostly accounted for climate change but the developing nations are those suffering more due to instability to cope as a result of poverty and low technological development (Odjugo, 2010).

The intergovernmental Panel on Climate Change (IPCC) and major scientific organizations of industrialized countries have concluded that the increase in global temperature since the middle of twentieth century has been due mainly to human induced (anthropogenic) greenhouse gases concentration via the greenhouse effect, while the warming effect caused by natural phenomenon such as solar variation contributed a small warming effect from pre- industrial times to 1950s and from then a reverse cooling effect began (Olaniyi et al., 2014; IPCC, 2007 and IPCC, 2014).

Climate and environmental changes are also as a result of human activities. Thus, Barade (2009) stated that our planet is unique to support life. However, within the limitations of our understanding of the terms, evolution and progress, human beings contributed a number of disastrous climate change triggers. Some of them are increased carbon dioxide emission, increase in greenhouse gas levels, and increase in land, water and air pollution levels. He is therefore of the view that the high level of industrial pollution and a number of human induced processes have resulted in climate change and environmental hazards. Kwan et al., (2011) are of the opinion that pollution is the process by which substances are added to the environment or the addition of materials to the environment that damages or defiles it, making it undesirable or unfit for life. These materials according to them are called pollutants. They further explained that as human populations increase and as society become more industrialized and urbanized; the problem of pollution has become more serious. Obviously, many of the products of modern technology which find their ways into the air and water are toxic and harmful to life of organisms and the entire ecosystem. Below are outlines of environmental pollutants caused by human activities. 
Air pollutants - air pollution occurs as a result of incomplete burning of fuels such as coal, oil, petrol and wood (Kwan et al., 2011). Apart from human activities, the gaseous pollutants emitted into the air can also be by natural occurrences such as biological decay, forest fires or volcanic eruptions as mentioned earlier. These harmful gaseous pollutants include; sulphur dioxide, nitrogen oxides, carbon dioxide, carbon monoxide and lead.

Sulphur dioxide and nitrogen oxides- these occur as a result of the burning of fossil such as coal, oil and natural gases. Sulphur dioxide at a very high concentration has damaging effects on both plants and animal lives. In the case of plants, it penetrates the leaves through the stomata (tiny opening in the cells of the leaves) and kills the plants. In the case of humans, sulphur dioxide causes irritation and damaging of the sensitive lining of the eyes, air passages and lungs. When this occurs for long time in an environment, it causes respiratory diseases. Furthermore, it is also important to state that, when sulphur dioxide and nitrogen oxide react with oxygen and rain water, they form sulphuric acid and nitric acid respectively. Rain water containing these acids is called acid rain. The presence of acid rains in lakes and rivers causes the death of fish and other creatures in so many countries of the world today. Kwan et al., (2011) also opined that sulphur dioxide is the main component of killer smog; which is a mixture of smoke and fog. Normally when smoke is emitted during burning, it is blown by the wind, and it goes to mix with the cool air. This mixture is prevented from escaping by a layer of warm air which acts like a cover above it. The mixture of the cool air and the pollutant remains stagnant air until it forms high concentration to produce lethal results. This causes respiratory problems (Kwan et al., 2011).

Lead -it is possible to find the presence of lead in the food we eat, the water we drink and the air we breathe in. A long time accumulation of lead in the body system could lead to high concentration of lead which may result to cramps, loss of control of hands and feet, and sometimes coma and death. Air in cities has higher presence of lead than the air in rural areas.

Carbon monoxide - the exhaust of motor vehicles, generators, air crafts, motorcycles and other forms of engines that emit such gases are the sources of carbon monoxide. When carbon monoxide is breathed in, it combines with haemoglobin in the red blood cells to form "carboxyhaemoglobin" which reduces the capacity of the blood to transport oxygen round the body. The may be very harmful when it occurs in high concentration and could be attributed to most deaths that occur when people confine themselves to areas where carbon monoxide is emitted without cross ventilation.

Carbon dioxide - this factor though primarily caused by human activities through the burning of organic compounds which results to the releasing of carbon dioxide into the air, yet has some natural implications. As such, carbon dioxide is the most important gases that cause "Greenhouse effects". This occurs when the sun rays hit the earth surface, but when they are reflected back into space, they are trapped in the atmosphere. The sun rays cannot escape from the earth's atmosphere, and the earth heats up; in other words, certain atmospheric gases like carbon dioxide, water vapour, and methane have the ability to change the energy balance of the earth by being able to absorb "long wave radiation" emitted from the earth's surface. The result of this may be global warming. The possible effect is that the world temperature may rise; Icebergs may melt, leading to an increase in quantity of water in the oceans.

Chlorofluorocarbons (CFC3) - These are non-toxic, unreactive chemicals. They are used as aerosol propellants, as cooling agents in refrigerators and air conditioners, and in foam packaging. Chlorofluorocarbon is released into the atmosphere from aerosols and other sources break down the Ozone layer of the atmosphere. The Ozone is a gas that forms a layer over the Earth and it absorbs much of the ultraviolet rays from sunlight. So when the Ozone is broken down; more ultraviolet light reaches the Earth. This increases the risk of skin cancer (Kwan et al., 2011).

Dust - these are smooth, fine dry particles of matter. So much dust is released into the atmosphere due to human activities like, construction, sweeping, mining, cement industrial sites and other sites. Industrial processes produce a lot of toxic materials. For instance, asbestos dust is believed to be the major cause of lung cancer in industrial worker who inhale them for long period of time. Natural 
phenomenon such as volcanic eruption, burning of garbage, chimney fumes, also causes the release of dust into the atmosphere.

Fumes - these are gaseous products or anything which contains airborne solid particles that are smaller than dust fumes are normally generated by incineration plants and industrial plants and can remain in the atmosphere even far from the place where it was released from. These fumes cause severe irritation of the respiratory system in human beings.

Pollen grains- these are usually released by flowers. These pollen grains are very small in size and as such can travel a very long distance. When they are inhaled, they can trigger allergic reactions in humans.

Water pollutants - Rivers, streams and lakes are polluted by waste materials dumped into them by humans. These affect communities that live in such areas.

The following are the various ways water can be polluted;

Sewage- when untreated sewage is discharged into rivers and lakes, they cause the breathing of bacteria. Bacteria grow and multiply using up the oxygen in the water, thereby causing fishes and other organisms in the water to die. These bacteria can also continue to break down the organic wastes, thereby releasing foul-smelling gases like hydrogen sulphide and ammonia. Untreated sewage also causes diseases like cholera and typhoid which sometimes get into wells, bore-wholes and sources of drinking water, which may result to epidemics.

Fertilizers- these are chemicals used by farmers to increase yields of crops. The fertilizers contain nitrates and phosphates which are useful nutrients for the growth of algae and plants. However the over use of chemical fertilizers may cause water pollution in the sense that fertilizers that are not absorbed by crops may be washed away by rainwater into nearby rivers and lakes. These are harmful to water organisms.

Inorganic wastes- these include industrial wastes such as poisonous metals like, mercury, arsenic and cadmium. These can be disposed of into rivers, streams and lakes. This can be illustrated by what happened in Minamata, a coastal town in Japan in 1972. A plastic factory had discharged waste water containing high concentration of mercury. About 40 people who eat the contaminated fish and shellfish died of mercury poisoning. About 70 people were crippled; blinded or paralyzed (Nwankwoala, 2015).

Pesticides - these are substances used to kill pests that destroy crops in farms. They include insecticides and herbicides. Insecticides are specifically used to kill insects. When applied to farms, they can be carried by rain water into rivers, streams and lakes. When they are in high concentration they may poison fish or animals that drink the water or feed on the contaminated fish. Again, insecticides DDT (Dichlorodiphenyltrichloroethane) are insoluble, and as such are stored in the fatty tissues of animals that consume them, and as such may result to serious health hazards. Also herbicides are substances used to kill weeds. Agriculturists are of the view that herbicides like " 2,4 , 5-T", contain an impurity called dioxin, which is harmful to human beings (Kwan et al., 2011).

Noise pollution - this is a type of pollution whereby excessively loud and unpleasant sounds of more than 80 decibels are produced. The world, especially African nations have become very noisy. There are heavy machineries, construction sites, mining activities that produce noise. Electrical gargets that produce noisy sounds like microphones, radios, megaphones, televisions, etc. are indiscriminately used in homes, cities, market places, streets, churches, mosques, hotels, club houses etc. Drivers of cars and Lorries blow horns of their vehicles at random. All these causes noise pollution which cause harm to humans. Prolonged exposure to noise can result in severe loss of hearing. Noise pollution in any environment can also cause emotional stress, irritability, lack of sleep or insomnia, high blood pressure psychological disturbances and low work productivity (Onuoha, 2012). 
Soil pollution - these are the build-up of chemical substances and other waste materials from factories in the soil. The presence of these substances makes the soil to lose its fertility and lead to the leaching of nutrients into water, and death of plants, crops or even animals. Other causes of soil pollution include (Kwan et al., 2011);

i. Inorganic nutrients like nitrates and phosphorous from the use of fertilizers;

ii. Toxic chemicals from the indiscriminate use of pesticides;

iii. Oil spill from oil pipes;

iv. Heavy metals such as chromium, cadmium and copper from smelting industries;

v. Liquid sewage wastes;

vi. Solid wastes such as rubbish, domestic refuse, paper, plastic and glass.

\subsection{Evidence of climate change in Nigeria}

Human influence on the climate system is clear, and recent anthropogenic emissions of the greenhouse are highest in history. Recent climate changes have had widespread impacts on human and natural systems. Climate change is already happening and small changes in average conditions such as sea level, or temperature can result in large changes in frequency of extreme events which are highly detrimental to our society. A $20 \mathrm{~cm}$ rise in sea level will inundate $3,400 \mathrm{~km}$ of Nigerian coastland and $100 \mathrm{~cm}$ rise in sea level will cover 18,400 km and submerge the Delta's entire oil and gas infrastructure (Onofeghara, 1995). Nigeria is experiencing adverse climate conditions with negative impacts on the welfare of the citizens. It is estimated that between 75 million and 250 million people of Africa may be exposed to increased stress such as scarcity of water, environmental stress and food security stress, due to climate change by 2022 (IPCC, 2014). Due to climate change, the areas suitable for agriculture, the length of farming seasons and yield potentials are expected to decrease.

Climate change has been confirmed following release of the by $4^{\text {th }}$ IPCC Assessment report, Africa will be worst hit by the effect of climate change where Nigeria is part of. As a result of this Nigeria is vulnerable to the effects of climate change. Available evidence show that climate change will be global, likewise its impact, but the biting effects will be felt more by the developing countries, especially those in Africa due to their low level of coping capabilities (Nwafor, 2007; Jagtap, 2007). Researchers have shown that Nigeria is already plagued with ecological problems which have been linked to ongoing climate change (Adefolalu, 2007; Ikhili, 2007). Recent evidence indicates that the world has already warmed by $0.8^{\circ} \mathrm{C}$ since pre-industrial era and under a Business as Usual (BAU) scenario, global mean temperature could reach about $2^{\circ} \mathrm{C}$ by 2060 (PACJA, 2009). Climate change and global warming if left unchecked will cause adverse effects on livelihoods in Nigeria such as forestry, crop production, livestock production and fisheries because the rainfall regimes and patterns will be altered, floods which devastate farmlands will occur. The intensity and seasonal nature of the rains cause drastic changes in rainfall patterns with rising temperatures introduce unfavourable growing conditions. Climate change modifies growing seasons which could subsequently reduce productivity.

Elevation of average annual temperatures causes the warming of the atmosphere known as global warming Increase in temperate and humidity would cause increase in pests and diseases. Natural disasters like sea level rise, floods, drought and storms surges are anticipated which may cause great havoc to lives and properties. In areas such as the Niger Delta and the North-east, these sequences of events are already unfolding on a limited scale (Nebedum and Nnaemeka, 2016).

The above evidences confirm that the effects of climate change have already been felt in many parts of the country. 


\subsection{Impacts of Climate Change in Nigeria}

Nigeria is indeed at risk to the effect of climate change in diverse spheres. Raheem, (2011) notes that Nigeria is particularly vulnerable to the impact of climate change on many fronts considering its geography, climate, vegetation, soils, economic structure, population and settlement, energy demands and agricultural activities. Watson et al., (1998) suggest that vulnerability is highest where there is an utmost sensitivity to climate change as well as the least adaptability. According to the OECD report in 2008, many of the poorest countries in the world, in Africa and South Asia, are likely to be hardest hit by climate change. This could be attributed to the prevailing less-adaptive capacity, which cut across several sectors including policy, government, and infrastructure. Nigeria's vulnerability to the impact of climate change has been documented in diverse sectors of the country (Oladipo, 2010). Although Nigeria has a strong economy relative to other countries in Sub-Saharan Africa, a significant part of its population and economy are linked to activities that are climate sensitive, such as gas flaring, rainfed agriculture, and inefficient transport system amongst others. Considering the low-level adaptive capacities and various negative impacts of climate change that have been recorded, scholars are in agreement that poorer nations are much more vulnerable to climate change than economically advanced countries. This is due to poor countries dependence on rain-fed agriculture, scarcity of resources needed to pursue adaptation measures (Fischer, et al., 2005; Okolie, et al., 2012).

Available data has shown that the "Earth's average surface temperature has risen by $0.75{ }^{\circ} \mathrm{C}\left(1.33{ }^{\circ} \mathrm{F}\right)$ since the 1880s". The ecological effect of climate change in Nigeria is seen in the disturbing patterns of rainfall, a decrease in some region and an increase in other regions and sea level rise. Existing indicators are also present in Nigeria and heralding the potentials of further damage. The fluctuating weather patterns, sea level rise, disturbing seasonal cycles, and atmospheric conditions, as well as water supply, are some of such indicators (Odjugo, 2005; Chindo and Nyelong, 2004; NEST, 2003). Already existing data have shown that there has been a change in the pattern of rainfall over the past decades, which is an indication of a rapid change in the climate (Oladipo, 1995; Anyadike, 2009) Anyadike (2009) suggests that the impact of climate change on human environment is evident in the changes in the inception and completion of rainfall, melting of ice caps which is caused by rising in sea level, extreme patterns in distribution of rainfall (extreme or deficient), which leads to flooding and increased intense atmospheric disturbances such as thunderstorms.

\subsection{Environmental impact}

As earlier noted, coastal and desert-prone regions experiences climate change-related challenges more than other areas. Coastal towns are usually populated and crowded. The sea level rise could disrupt social and economic activities and physically endanger teaming inhabitants of the area. According to Oladipo (2010), sea level increase of $0.5-\mathrm{cm}$ for Nigeria coastlines is been predicted, and this will affect the environmental and socioeconomic activities going on in those regions. The surge in rainfall in the coastal cities of Warri, Port Harcourt and Calabar has been the reason for the increasing floods, ravaging those areas. In some coastal localities in the Niger Delta region, settlements have been uprooted while some oil wells have been lost to the ocean due to erosion (Ogundebi, 2004; Ikhile, 2007; Nwafor, 2007; Umoh, 2007; Odjugo, 2010). In addition to this, available report highlights that sea-level rise and repeated ocean surges can worsen coastal erosion problems that are currently a serious challenge in the coastal areas (NEST, 2004; Uyigue, et al., 2007). More so, the economy of the nation is hugely dependent upon the economic resources that are located in the coastal regions.

A very substantial land mass of Nigeria is already prone to desertification. In some northern parts of Nigeria "expanding desertification, which refers to the degradation of land productivity in dry land areas has caused 200 villages to disappear"(Werz and Conley, 2012). The Savannah area in Nigeria is highly susceptible to a continuous reduction in rainfall, thus, it could lead to widespread degradation of the habitat. It has been projected that the amount of rainfall in the savannah is likely to decrease (FME, 2011; Ajibola, 2014). The decrease in output from the upsurge of desertification will indeed perpetuate our susceptibility to climate change and thus deepen the hitches of climate change, especially in a scenario where there is a heavy dependence on nature for productivity. Water, which is 
an important resource in the country, used in hydro-power stations such as dams are affected by drought. Besides, while they serve as good water supply and are renewable energy they also emit greenhouse gases (Bryson et al., 2008). The mangroves that support the ecosystem of the coastlines are disappearing. The implication is that there is a surge in the salinization of upland groundwater.

\subsection{Health impact}

Climate change impacts on health in many ways. Africa is particularly known for its vulnerability to many climate-sensitive diseases such as malaria, tuberculosis, and diarrhea (Thomson, et al., 2004; Guernier, et al., 2004). The health impacts of climate change include heat-related illnesses, extreme weather-related injuries, the spread of infectious diseases such as water- and food-borne diseases, upsurge of respiratory disorders, vector-borne diseases and, stress-related and mental health disorders (Costello, et al., 2009). Mshelia (2005) and Adefolalu (2007) claim that climate change has affected agriculture and health in Nigeria. A swing in the cycle of rainfall and weather conditions will promote the prevalence of some diseases such as malaria, due to the increased incidence of pools and standing waters. Floods are also increasing in frequency and intensity in the region and may contaminate freshwater supplies, heighten the risk of water-borne diseases and create breeding grounds for disease-carrying insects such as mosquitoes. Climate change is likely to trigger the prevalence of diarrhea, epidemics like cholera and other vector-borne diseases. It also impacts the environmental basis of good health including clean air. Toxicity is common and caused by air pollution via the burning of fossil fuels from generators and transportation industries.

In relation to geographical distribution, organisms that ordinarily do not survive in colder regions are fast moving to those regions, presuming their survival and endangering humanity in those areas. Rising temperatures may mean that a vector becomes sustainable at different latitudes and altitudes, exposing new populations to the disease. Warmer oceans may result in outbreaks of diseases. More so, warmer temperatures are associated with increased allergy-related diseases like asthma. Changes in climate are likely to lengthen the transmission seasons of important vector-borne diseases and alter their geographic range (Mshelia, 2005).

\subsection{Economic impact}

The sensitivity of climate change in Nigeria's agricultural productivity is quite imminent. Agriculture in Nigeria has already been altered by climate change (Mshelia, 2005; Adefolalu, 2007). For centuries, agriculture has been a source of income and livelihood to individuals and communities. Climatic changes, however, threatens this means of livelihood and nutrition of the nation. It also threatens food security and programmes aimed at the elimination of poverty (Onyenechere and Igbozurike, 2008). Agricultural practice in the country is predominantly rain-fed and therefore particularly vulnerable to the impacts of climate change. The unreliability in the onset of rainfall in recent times, which determines the inception of agro-business, due to fluctuations in the pattern of rainfall often leads to a minimal harvest. Since Nigerians are largely involved in the rain-fed agricultural system, climatic changes will adversely impact the amount and timing of rainfall in subsequent times. Invariably, climate change is likely to decrease the production of the arid regions as a result of desertification. Ayuba et al., (2007) reveals that continuous loss of forest cover and biodiversity in Nigeria is linked to climate change. Onyenechere (2011) suggests that coastal regions that rely heavily on fishing may also be hit as climate change upsets ocean currents and fisheries. Climate change equally increases the incidence of pests and diseases that attack and decimate forest trees. The incidence of pest and diseases of crops are also heightened in the arid zones as a result of climate change. Climate change is likely to create pressure on food supplies thereby, heightening malnutrition. Generally, the effect of climate variations on agro-business may have an enormous impact on food production, revenue, and employment.

Deviations in the strength and pattern of storms are dynamics that may have an impact and increase the risk of flooding. Flooding plays a number of roles in affecting the lives and activities of the 
individual personally and collectively. On the individual level, it floods houses and apartments, bringing about damage to infrastructure and properties in homes, the prevalence of malaria and diseases due to persistent occurrences of stagnant water in the neighbourhood. At the community level, it contributes to an inefficient transport system due to damaged roads. Extreme weather events such as thunderstorms, heavy winds, and floods, devastate farmlands and often lead to crop failure (Adefolalu, 2007).

Human influence on the climate system is clear, and recent anthropogenic emissions of greenhouse gases are the highest in Nigeria like all the countries of Sub-Saharan Africa is highly vulnerable to the climate change (NEST, 2004; Apata et al., 2009; IPCC, 2014)

\subsection{Measures to Reduce High Risk of Climate Change}

The main challenge, the world over, is to keep climate change from becoming a catastrophe. Generally, there are two broad major approaches to dealing with climate change-related challenges; these are mitigation (which means to tone down, diminish or lessen human activities that may aggravate the increase of greenhouse emissions) and adaptation (which refers to the modification and changes to reduce the impact of climatic variations in the environment). While mitigation seeks to limit climate change by reducing climate change through the reduction of the emissions of greenhouse gases and by enhancing 'sink' opportunities, adaptation aims to alleviate the adverse impacts through a wide-range of system-specific actions.

Overcoming the development challenge of climate change requires that more extensive adaptation and mitigation measures that are currently being applied are necessary to reduce vulnerability to future climate change. Future vulnerability will depend not only on the degree of climate change but also on the development "pathway" taken, as well as capacity put in place to cope with the climate change stress. Mitigating greenhouse gas emissions and enhancing the adaptive capacity to increase resilience can accelerate the pace of progress towards sustainable development. Adapting to climate change involves reducing exposure and sensitivity, and increasing adaptive capacity to build a climateresilient society. This will be a society that is able to withstand or recover fast from difficult conditions caused by the adverse effects of climate change, including climate-related hazards and disasters (Ifeanyi-Obi et al., 2012).

Climate change is a threat to sustainable development. Nonetheless, there are many opportunities to link mitigation, adaptation and the pursuit of other societal objectives through integrated responses (high confidence). Successful implementation relies on relevant tools, suitable governance structures and an enhanced capacity to respond (medium confidence). Effective adaptation and mitigation responses will depend on policies and measures across multiple scales: international, regional, national and sub-national. Policies across all scales supporting technology development, diffusion, and transfer, as well as finance for responses to climate change, can complement and enhance the effectiveness of policies that directly promote adaptation and mitigation. Adaptation and mitigation are complementary strategies for reducing and managing the risks of climate change. Substantial emissions reductions over the next few decades can reduce climate risks in the 21st century and beyond, increase prospects for effective adaptation, reduce the costs and challenges of mitigation in the longer term and contribute to climate-resilient pathways for sustainable development (Olaniyi, et al., 2014; Chuku and Asiegbu, 2010; Nebedum and Nnaemeka, 2016).

\subsection{Mitigation}

This is a means through which the causation of climate change can be stopped. It is about reducing human activities that intensifies the emission of the gases which perpetuates global warming. According to IPCC (2001), the mitigation options include a reduction in the burning of fossil fuels and reduction of greenhouse gases; reduction of deforestation, an increase in reforestation and 
afforestation; modification of agricultural practices to reduce the emission of greenhouse gases and build up soil carbon. There still exist other routes of mitigation such as the use of GIS and remote sensing in monitoring the environment. Atilola (2012) suggests that "another mitigation option which is geoengineering to reverse the effect of global warming by creating cooling effects which will offset greenhouse heating and conceiving the development of technology for cleaning the greenhouse gases from the atmosphere".

Sharma and Kumar (1998) and Kates (2000) among others, state that greater consideration has been given to climate change mitigation than to adaptation measures. The multidimensional mitigation methodology is aimed at achieving a low-carbon society. OECD, (2008) asserts that "Mitigation is achieved by reducing both the energy intensity of GDP and the carbon intensity of energy used". A number of researches have been made by organizations and individuals on best mitigation practices and policies. According to IPCC (2007), "some mitigation practices that can be employed are use of renewable heat and power (hydropower, solar, wind, bioenergy), non-motorised transport, for example, walking and cycling, improved cook stoves, alternative refrigeration fluids, deforestation, improved crop and grazing land management and so on, other measures that can be taken up as mitigation practices includes: waste recycling and reforestation.

Many adaptations and mitigation options can help address climate change, but no single option is sufficient by itself. Effective implementation depends on policies and cooperation at all scales and can be enhanced through integrated responses that link adaptation and mitigation with other societal objectives (Onyenechere, 2010). Adaptation and mitigation responses are underpinned by common enabling factors. These include effective institutions and governance, innovation and investments in environmentally sound technologies and infrastructure, sustainable livelihoods and behavioural and lifestyle choices. Mitigation options are available in every major sector. Mitigation can be more costeffective if using an integrated approach that combines measures to reduce energy use and the greenhouse gas intensity of end-use sectors, decarbonize energy supply, reduce net emissions and enhance carbon sinks in land-based sectors (Ogbo and Onyedinma (2012).

Agriculture is a significant contributor to greenhouse gases, particularly in a developing country like Nigeria. It is estimated that about $10-12 \%$ of total anthropogenic emissions of greenhouse gases are directly generated in agriculture (mostly nitrous oxide from fertilized soils and methane from livestock). If indirect emissions from the fertilizer industry and emissions from deforestation and land conversion are added, the total contribution of the agriculture sector is increased to about 26-35\%.

A variety of options for mitigation (reduction of greenhouse gases) exist in agriculture. They fall into three broad categories:

i. Reducing emissions of methane, carbon dioxide, and nitrous oxide through efficient management of the flows of these gases in agricultural ecosystems for example, through managing livestock to make more efficient use of feed (Atitola, 2012; Ifeanyi-Obi et al., 2012).

ii. Enhancing the removals of carbon dioxide through improved management of forestry and agro ecosystems for enhanced carbon recovery and carbon storage. Afforestation and reforestation are measures that can be taken to enhance biological carbon sequestration. Nigeria can focus on the potential to use forests as one of the strategies towards becoming carbon-free (Adejuwon, 2016).

iii. Avoiding emissions using crops and residues from agricultural lands as a source of fuel, either directly or after conversion to fuels such as ethanol or diesel. Greenhouse gases emissions, notably carbon dioxide, can also be avoided by agricultural management practices that forestall the cultivations of new lands now under forest, grassland or other non-agricultural vegetation (Apata, et al., 2009; Ozor, 2009; Ifeanyi-Obi et al., 2012). 


\subsection{Adaptation}

Adaptation is simply an attempt to limit susceptibility to climate change impact. According to Ogbo and Onyedinma (2012), "adaptation involves the action that people take in response to, or in anticipation of projected or actual changes in climate to reduce adverse impacts or take advantage of the opportunities posed by climate change". It is a method of dealing with the symptoms to reduce the vulnerability of ecosystems to climate change and not the underlying causative factors. Basically, adaptation is a means by which individuals lessen the negative effect of climate variations on their wellbeing. It helps to shrink the susceptibility of ecosystems to the impact of climate change. According to Onyenechere (2010), "adaptation to climate change is a response to climate change that seeks to reduce the vulnerability of natural and human systems to climate change effects". The need to adapt to the variability of the climate is a basic one. It is important that states and individuals engage new methods for living a positive impact on the climate. The adoption of adaptation strategies is most important for developing countries, including Nigeria, as they suffer the impact of climatic variations that has serious implications for their socio-economic development. Slobodan (2012) has also suggested that adaptive capacity is closely linked to social and economic development.

Adaptation options exist in all sectors, but their context for implementation and potential to reduce climate-related risks differs across sectors and regions. Some adaptation responses involve significant co-benefits, synergies, and trade-offs. Increasing climate change will increase the challenges for many adaptation options (IPCC, 2007).

\subsection{Adaptation strategies for Nigeria}

Adaptation strategies are steps that can be taken to cushion or decline the effect of active or presumed climate fluctuations in the ecosystem. Climate change adaptation is basically a process that involved ecological, social and economic systems adjustment to likely and actual climatic stimulus and their respective impact (Nzeadibe et al., 2011). Nigeria may need to employ more of adaptation strategies because, like other developing nations, the country is not largely involved in climate threatening industrialization when compared with most developed countries. Furthermore, the country is not yet technologically advanced to engage the needed infrastructure necessary for many forms of mitigation practices. The harmful effect of climate change can be reduced if the necessary adaptation measures are employed (Ogbo and Onyedinma, 2012).

\section{(i) Health care}

Due to the increased temperature of the earth, water-borne diseases such as malaria have increased. Rural communities in Nigeria are hugely susceptible to cholera outbreaks. It has been therefore suggested that rainwater harvesting tanks should be encouraged in homes instead of salinized groundwater which may have been subjected to contamination. Health surveillance systems should be encouraged by the government and local communities. Technologies that reduce our exposure to extreme heat should be adopted. The efficient health care system should be pursued and the primary health care system should be strengthened, restructured and expanded local communities. Improvement in housing conditions for the masses is also needed (Nzeadibe et al., 2011)..

\section{Desertification}

For the arid zones where desertification threatens, an innovative project like the great green wall which is on-going is encouraged. Improved species that have the adaptive capacity should be made accessible to farmers for planting. Soil and water conservation technologies should be pursued. The pit planting technique will be of immense benefit for collecting surface runoff water and making them available for agriculture. The use of irrigation should be improved and widely promoted in the arid zones (Odjugo, 2008). 
(iii)

Flood control

The construction of efficient drainages that create an effective pathway for the movement of flood in erosion-prone areas in local communities will be of immense help. The erection of canals and guardrails is required in both local and urban communities. It will also help to reduce pollution, waterborne disease and vectors that breed and incubates in standing waters. Flood control mechanisms are required to salvage coastal communities and crops from torrents and over flooding. More so, the construction of a sea wall would be an additional advantage in the management of flood in flood-prone areas (Nwafor, 2007).

\section{Human settlement}

Some urban and coastal regions have been displaced by the upsurge of floods in those areas. The employment of spatial planning an adaptation strategy in the planning of cities and urban areas is quite crucial. The flooding of local communities in some parts of the Niger Delta region caused a mass relocation farther into the inland areas in temporal and permanent terms, which contributes to the over-population of the area (Kyuba, 2012). The climate change adaptation demands infrastructure like protective barriers which helps to counter a rise in sea help in the management and retention of water. Efficient building strategies should be employed by construction firms to step up with the challenge. Innovative flood control and monitoring of drought are also encouraged. Efforts should be made by the government to construct cities in higher plains rather than closer to the floodplains which are more vulnerable (Kyuba, 2012)..

A good and fitting water management approach should be employed Avenues for water provision in the arid regions should be explored. Best practices on water management via the utilization of relevant technology can be used to conserve soil moisture. Efforts should be made by the government and relevant stakeholders to ensure the desalination of groundwater sources which is leading to the decline of life. Appropriate desalination technology should be engaged. Increased management of water supply and security of the coastal zones is also needed. Relevant laws and policies should be enacted by regulatory agencies to promote the safety of these coastal regions.

\section{(v) Meteorology and weather monitoring techniques}

Additional efforts should be made by the meteorological agencies on how to effectively predict changing weather conditions and zones to equip the government and the people with relevant information that is needed to escape, prevent and reduce losses that may result from climate change. Efforts should be made to engage weather monitoring technologies that give early warning signs and are better able to predict envisaged risk of weather variations. Capacities building of relevant stakeholders and institutions to better adapt to climate change at the national and local levels is essential (Atitola, 2010).

Adaptation can be both autonomous and planned. Autonomous adaptation is the ongoing implementation of existing knowledge and technology in response to the changes in climate experienced, while planned adaptation is the increase in adaptive capacity by mobilizing institutions and policies to establish or strengthen conditions that are favourable to effective adaptation and investment in new technologies and infrastructure. Various sectors will have their adaption measures.

\subsection{Best practice principles}

Whatever mitigation and adaptation measures are being considered for adoption or implementation, they must be guided by good practice principles. Good practices are actions that are effective in meeting established goals and deemed to be appropriate and acceptable by a broad range of stakeholders. In climate change response, these may include: 
The most important variable that determines whether the State is able to address the challenge of climate change and achieve sustainable development is human and institutional capacity and appropriate regulatory and legal framework. Projects designed to mitigate or adapt to climate change in the State should, therefore, ensure that local capacity is built during their implementation. In this regard, mitigation and adaptation projects must integrate training programmes into core project activities and measures taken to assure that built human capacity is maintained and replicated beyond the project's lifetime (Osman-Elasha, 2010; Ogbo and Onyedinma, 2012).

\section{Knowledge building}

The complex and dynamic nature of climate change makes it imperative for the need to undertake research into its physical and socio-economic basis for an improved national understanding of the global dimensions of climate change and to be able to communicate the issues to the general populace through a coordinated advocacy and awareness creation strategy. Empowering the populace through improved knowledge about the climate change challenge will put them in a better position to identify, plan and implement adaptive measures that will enhance their resilience. In this regard, the designing of climate change projects must be built upon or applied to the findings of specific research projects and/or vulnerability studies. Also, there is a need to ensure that the projects actively contribute to national and international understanding of a specific topic or area of research (Osman-Elasha, 2010; Ogbo and Onyedinma, 2012).

Integrated programme approach

Climate change is a complex multi-sectoral environmental and development challenge. Fragmentation of issues across multiple policy platforms and narrowly bounded institutional mandates encourages unilateral, single-sector responses, discourages innovative leadership and inhibits the development of policy actions informed by the full complexity of climate change challenges. Thus, sectoral and smallscale uncoordinated interventions will not adequately address the challenge of climate change in the State for impact. A multi-sectoral national programme, financed and implemented in a coherent and integrated manner over a period of time is imperative for an effective state response to the challenge of climate change, within a national framework. What is required is a state programme of action (minimum 10 years' timeframe), developed through stakeholders' consultations, properly financed and implemented in an integrated manner through various institutions, but led by the Ministry of Environment, particularly the Climate Change Unit (IPCC, 2007; IPCC, 2014).

\section{Transferable to other context or regions}

Projects designed to mitigate or adapt to climate change must ensure that their activities can be transferred beyond the specific contexts in which they were implemented. Particular project measures, activities or concepts should be easily applied in another context or region (IPCC, 2007).

\section{Community participation and inclusiveness}

Climate change management in Nigeria requires a shift to an integrated approach that advances change responses which are closely intertwined with development choices and driven by multistakeholder identification (up to community level) and implementation of priority mitigation and adaptation measures. In this regard, the State Ministry of Environment, particularly the Climate Change Unit, will have to lead a process of collaborating with relevant MDAs to formulate and mobilize resources for the implementation of sectoral programmes and projects, particularly in climate-sensitive sectors such as agriculture, water, health, energy, infrastructure and so on. In other words, projects designed to mitigate or adapt to climate change in the State must result from 
consultation with local communities in the formulation, implementation, and decision-making process, with the incorporation of gender issues (IPCC, 2007; IPCC, 2014).

(vi) Political ownership, collaboration, and approval

Projects designed to mitigate or adapt to climate change need to secure high-level political support for their activities and be aligned with wider development agendas to ensure success. Thus, the Ministry of Environment will need the support of the high-level governance in the State for the establishment of an enabling policy, legal and regulatory framework for the state's response to climate change in order to be able to develop and implement a comprehensive mitigation and adaptation programme measures (IPCC, 2007; IPCC, 2014).

(vii) Financial sustainability

Financing for climate change mitigation and adaptation activities will be costly if the State is to fully address the challenge of climate change. Annual budget allocations will be extremely inadequate to enable states implement an integrated response to the challenge of climate change. What is required is a pool of resources into which state and external funds can be made available on a sustainable basis to upscale state response for effectiveness. This will ensure that projects designed to mitigate or adapt to climate change in the state secure financing for sustaining and/or expanding the project's impacts beyond the initial project lifetime (Ajibola, 2014).

(viii) Achieving co-benefits and balancing the trade-off

Projects designed to mitigate or adapt to climate change must take into consideration the costs and benefits external to the project such as employment, environment, health, poverty levels and food security. Projects must aim to maximize external co-benefits from project activities and avoid/minimize external costs and damages (Ajibola, 2014).

(ix) Monitoring and evaluation

Projects designed to mitigate or adapt to climate change in the State must demonstrate their impacts in terms of achieving the project objectives, outcomes, and outputs, as well as developing indicators to measure success and effectiveness. In other words, good mitigation and adaptation projects must have an explicit logical framework with appropriate monitoring and evaluation mechanisms (Ajibola, 2014).

Improving energy efficiency

This includes the use of efficient production technologies and a behavioural change in energy use. Renewable energy use is therefore the best option because of its efficiency (Uyigue et al., 2010).

(xi) Reducing vehicle emissions

Through a number of policies that encourage cleaner fuel use and promotion of mass transit schemes, including bus rapid transit (BRT) coupled with the integration of non-motorized transport in urban areas while shifting freight from road to rail and water transport (Osman-Elasha, 2010; Ogbo and Onyedinma, 2012). 
(xii) Reducing greenhouse gases emissions in agriculture

Through the use of improved technologies, including (i) applying modern irrigation and water management practices; (ii) applying fertilizers tailored to the condition of the soil; (iii) strengthening the management of animal waste, the treatment of solid and liquid waste, and using methane emissions to produce renewable energy (Adejuwon, 2006, Ajibola, 2014).

(xiii) Managing waste to reduce methane emissions

This includes conversion of solid waste into compost and organic fertilizer; recovering methane from landfills, recovering energy during waste incineration and controlling wastewater treatment (Nzeadibe et al., 2010).

(xiv) Response to climate change as a shared responsibility

This means that every individual, firm, and government has a responsibility to protect the environment to make it more climate-friendly (Oladipo, 2010).

(xv) Promoting carbon-neutral lifestyles

Carbon-neutral lifestyles among individuals must be promoted and promoting carbon-neutral products or services for government support (Osman-Elasha, 2010; Ogbo and Onyedinma, 2012).

\section{(xvi) Reversing deforestation}

Deforestation accounts for between 20 and 25\% of global carbon dioxide Agroforestry systems; in particular, contribute simultaneously to buffering farmers against climate variability and changing climates, and to reducing atmospheric loads of greenhouse gases. Thus, reversing deforestation, through appropriate policies and programmes, is critical for climate change mitigation; it is also a relatively low-cost strategy (Adejuwon, 2006).

\subsection{Conclusion and Policy Recommendations}

\subsection{Conclusion}

The paper examined the impacts of climate change on Nigeria ecosystems. The impact of climate change on ecosystems is extensive. Climate change is a driving force that can weaken sustainable economic and environmental development; and inhibit the realization of the millennium development goals. Some of the characteristic features of these climatic alterations are seen in the changes in temperature, rainfall, and precipitation, global warming, desertification, drought, increased melting ice caps and glaciers, which causes sea level rise and in turn flooding. These challenges are already evident in Nigeria. The country, therefore, needs to increase and improve on its adaptation strategies to forestall further degradation and associated challenges on the human and national economy. Integration and mainstreaming of various adaptive measures outlined above need to be consciously and effectively drawn into the national plan and pursued vigorously in order to reduce the negative impact of climate change and ensure sustainable development of Nigeria. The government and people of Nigeria should take up the challenge and seek cooperation and collaboration with international agencies in order to reverse these undesirable outcomes. In the final analysis, stopping climate change is up to us. Our actions today will determine the climate tomorrow. By choosing to take action now will limit future damage. Government, of course, needs the active support of individuals, nongovernmental organizations and the private sector operators to enhance the state institutional and financial capacities imperative to effectively address the challenge of climate change in the country. Together the battle against the impact of climate change can be won. 


\subsection{Policy recommendations}

Nigeria is highly vulnerable to the impacts of climate change and must as a matter of urgency take drastic steps to reduce its vulnerability, build its resilience and its adaptive capacity. Henceforth, in order to deal with the adverse impact of climate change on the Nigerian ecosystems that affect the economy and society, certain mitigation and adaptation strategies have to be employed. The following recommendations are proposed:

i. There is a need for improved computer models of climate change over Nigeria which must include downscaling global circulation models using appropriate methods for understanding economic and social impacts, vulnerabilities and adaptation requirements.

ii. Sufficient attention must be paid to the impacts of climate change in Nigeria with a view to formulating adaptive strategies, resilience, and coping mechanisms.

iii. Renewable energy sources such as solar energy, hydro-power energy, wind energy, geothermal energy, etc. should be adopted and encouraged as alternatives to fossil fuel.

iv. Oil spillage and gas flaring in the coastal regions should be checked to help enhance carbon sink and depletion of the ozone layer.

v. The use of climate forecasting should be increased to reduce production risk.

vi. Encouraging the use of low-cost solar energy cookers instead of wood-burning devices which cause deforestation.

vii. Mass transport system including rail transport should be developed to reduce the proliferation of cars and motorcycles on our roads.

viii. An extensive study for an up-to-date greenhouse gas inventory, projection, mitigation, and adaptation strategies should be encouraged.

ix. The agricultural and research institutions should commence research into crops that are heat and drought resistance.

x. Building and developing plans for both urban and rural area development for proper settlement so as to reduce the vulnerability of the environment.

xi. Relocation of settlers in areas vulnerable to sea level rise and flooding, protection of natural barriers, the building of sea walls and dune reinforcement.

xii. Terrestrial and marine ecosystems that act as carbon sink reservoir to greenhouse gases should be protected and sustained by reducing bush burning and encourage afforestation.

xiii. The Ministry of Environment should check the erosion problem by the construction of dykes and storm surge barriers against sea level.

xiv. Trans-boundary water resources management, particularly across the West African subregion should be initiated.

xv. The existing government agencies and commissions saddled with the responsibilities for the strategic planning and coordination of national policies related to climate variability and climate change in Nigeria should be sufficiently strengthened to achieve the desired goals and objectives.

xvi. Improved understanding of the key drivers of climate variability and climate change in Nigeria.Consistent public engagement on climate change issues, to ensure that people appreciate the risks, understand policy decisions and have a voice in how they are implemented. 
xvii. To enhance public access to relevant information (e.g. weather data) that can be used effectively to make informed decisions at different time periods.

\section{References}

Adefalolu, D., (2007). Climate Change and Economic Sustainability in Nigeria, Paper presented at the International Conference on climate change and Economic Sustainability, Held at Nnamdi Azikiwe University Awka, Nigeria, $12^{\text {th }}-14^{\text {th }}$ June, 2007.

Adejuwon, J.O., (2006). Food security, climate variability and climate change in Sub-Saharan WestAfrica, Assessments of Impacts and Adaptation to Climate Change (AIACC), Project No. AF 23, A Final Report, AIACC Project Office, Washington, D.C.

Ajibola, A.O., (2014). Climate change effects on household agric-economy and adaptive responses among agricultural households in Nigeria, Contribution paper presented at the Centre for the Study of African Economies at St. Catherine's College, Oxford University UK, 23 ${ }^{\text {rd }}-25^{\text {th }}$ March.

Anyadike, R.N.C., (2009). Climate Change and Sustainable Development in Nigeria, Conceptual and Empirical Issues, Enugu Forum Policy Paper, vol. 10, African Institute for Applied Economics, Nigeria.

Apata, T.G., Samuel, K.D. and Adeola, A., (2009). Analysis of climate change perception and adaptation among Arable Food Crop Farmers in South-Western Nigeria, Paper presented at the conference of International Association of Agricultural Economics, pp. 1-9.

Atitola Olusola, (2010). Global Warming and the Nigerian Environment: The Imperatives, Surveying and Mapping Services, Presented at the National Conference of the Nigerian Union of Planetary and Radio Services (NUPRS), University of Lagos, Lagos State, $12^{\text {th }}-15^{\text {th }}$ October, 2010.

Ayuba, H., Marya, U. and Gwary, D., (2007). Climate Change Impact on Plant Species composition in six Semi-Arid Rangelands of North-eastern Nigeria, The Nigerian Geographical Journal, vol. 5, No.1, pp.35-42.

Blaiki, P., Cannon, T., Davis, I. and Wisner, B., (1994). At Risk: Natural hazard, people's vulnerability and disasters, London, Rutledge.

Bryson, B., Zbigniew, W. and Palutikof, J., (2008). Climate change and water, Intergovernmental Panel on Climate Change.

Chindo, A. and Nyelong, P., (2004). Lake Chad: From Mega Lake to Mini Lake, Arid Wetland Bulletin, No. 6, pp. 24-27.

Chukwu, G.U. and Asiegbu, A.D., (2011). Global Warming and Climate Change: Impacts and Implications in Nigeria, International Journal of Current Research, vol. 3, No. 6, pp. 112-115.

Costello, A., et al., (2009). Managing the Health Effects of Climate Change: Lancet and University College London Institute for Global Health Commission, The Lancet, vol. 373, pp. 1693-1733.

FAO (Food and Agriculture Organization of the United Nations), (2008). Climate change adaptation and mitigation in the food and agriculture sector, Technical background document from expert consultation held on $5^{\text {th }}-7^{\text {th }}$ March 2008, Rome..

Fatile, O.J., Akhakpe, I., Igbokwe-Ibeto, C. J. (2012). Local Government and the Challenges of Community and Rural Development in Nigeria: the Way Forward, International Journal of Asian Social Science, vol.2, No. 5, pp. 648-665.

Fischer, G., Shah, M., Tubiello, F. and Velhuizen, H., (2005). Socio-economic and climate change impacts on agriculture: an integrated assessment, 1990-2080, Philosophical Transactions of the Royal Society, Biological Sciences, vol. 360, pp. 2067-2083. 
FME (Federal Ministry of Environment), (2011). National Adaptation Strategy and Plan of Action on climate change for Nigeria (NASPA-CCN), Federal Ministry of Environment, Climate Change Department, Government of Nigeria.

Funmilayo, O.A. and Olutimchin, I.O., (2014). Review of climate change and its effect on Nigeria Ecosystems, International Journal of Environment and Pollution Research, vol. 2, No. 3, pp. 70-81.

Guernier, V., Hochberg, M. and Guegan, J., (2004). Ecology drives the worldwide distribution of human diseases, PLOS Biology, Oxford, vol. 2, No. 6, pp. 740-746.

Hans-Peter, M.I., Richwein, M., Richerson, W., Laurent, C., Snell, J., Burchert, E., and Lux, F., (2009). Floating Houses and Mosquito Nets: Emerging climate change Adaptation Strategies around the world, Boston: Meister Consultants Group, pp. 76-79.

Ikhile, C.I., (2007). Impacts of climate variability and change on the hydrology and water resources of the Benin-Owena River Basin, PhD Thesis submitted to the department of Geography and Regional Planning, University of Benin, Benin City, Nigeria, pp. 234-236.

Ifeanyi-Obi, C.C., Etuk, U.R. and Jike-Wai, O., (2012). Climate change, effects and adaptation strategies: Implication for agricultural extension system in Nigeria, Greener Journal of Agricultural Sciences, vol. 2, No. 2, pp. 53-60.

IPCC (Intergovernmental Panel on Climate Change), (2001). Climate change 2001: Impacts, Adaptation and Vulnerability, Working Group II, Contribution to the Third Assessment Report of the Inter-Governmental Panel on Climate change, "Chapter 18: Adaptation to Climate in the Context of Sustainable Development and Equity", Cambridge University Press, Cambridge, pp. 877-912.

IPCC (Intergovernmental Panel on Climate Change), (2007). Impact, Adaptation and Vulnerability, Contribution of Working Group I of the Intergovernmental Panel on Climate Change to the $3^{\text {rd }}$ Assessment Report of IPCC, London, Cambridge University Press.

IPCC (Intergovernmental Panel on Climate Change), (2014). Climate change, 2014 Synthesis Report, Contribution of Working Groups I, II and III to the $5^{\text {th }}$ Assessment Report of Intergovernmental Panel on Climate Change, IPCC, Geneva, Switzland, 151p.

Jagtap, S., (2007). Managing vulnerability to extreme weather climate events: Implications for agriculture and food security in Africa, Proceedings of the International Conference on climate change and Economic Sustainability, held at Nnamdi Azikiwe University, Awka, Nigeria, $12^{\text {th }}-14^{\text {th }}$ June 2007.

Kadafa, A., (2012). Environmental impacts of oil exploration and exploitation in the Niger Delta of Nigeria, Global Journal of Science Frontier Research Environment and Earth Sciences, vol. 12, No. 3, pp. 18-28.

Kates, R., (2000). Cautionary Tales: Adaptation and Global Poor, Climatic Change, vol. 45, pp. 5-17.

Kwan, M.P., Kenda, L.L., Wewers, M.E. Ferketich, A.K. and Klein. E.G., (2011). Sociogeographic context, protobacco advertising, and smokeless tobacco usage in the Appalachian Region of Ohio (USA). Paper presented at the 2011 International Medical Geography Symposium, Durham, UK.

Mshelia, A., (2005). Adaptation strategies to climate change, Journal of Environmental Energy, vol. 18, No. 3, pp. 74-81.

Nebedum, E.E. and Nnaemeka, V.E., (2016). Climate Change and its Impact in Nigeria, Journal of Scientific Research and Reports, vol. 10, No. 6, pp. 1-13.

NEST (Nigerian Environmental Study/Action Team), (2003). Climate change and Nigeria: A communication guide for Reporters and Educators, Ibadan, NEST, Nigeria, pp. 5-16. 
NEST (Nigerian Environmental Study/Action Team), (2004). Climate change and Nigeria: A guide for Policy Makers, Ibadan, Nigeria, pp. 27-40.

Nwafor, J., (2007). Global Climate Change: The Driver of multiple causes of flood intensity in SubSaharan Africa, Paper Presented at The International Conference on Climate Change and Economic Sustainability, Held at Nnamdi Azikiwe University, Awka, Nigeria, 12 $2^{\text {th }}-14^{\text {th }}$ June 2007.

Nwankwoala, H.N., (2015). Causes of climate change and environmental changes: The need for environmental friendly education policy in Nigeria.

Nzeadibe, T.C., Egbule, C.I., Chukwuone, N.A. and Agu, V.C., (2010). Climate change awareness and adaptation in the Niger Delta region of Nigeria, African Technology Policy Studies Network, Working Paper, No. 57.

Obire, O. and Barade, W.N. (2009). Impact of Industrial Activities on the Physico-chemistry and Mycoflora of the New Calabar River in Nigeria, E.K. Yanful (ed.), Appropriate Technologies for Environmental Protection in the Developing World, Springer Science + Business Media, pp. 152-159.

Odjugo P.A.O. (2001a). Global warming and food production: A global and regional analysis. African Journal of Environmental Studies, 2(2), pp. 85-91.

Odjugo, P.A.O., Ikhuoria, A.I., (2003). The impact of climate change and anthropogenic factors on desertification in the semi-arid region of Nigeria, Global Journal of Environmental Science, 2(2), pp. $118-126$.

Odjugo, P.A.O., (2005). An analysis of rainfall pattern in Nigeria, Global Journal of Environmental Science, 4(2), pp. 139-145.

Odjugo, P.A.O., (2009). Quantifying the cost of climate change impact in Nigeria, Emphasis on wind and rainstorm, Journal of Human Ecology, 28(2), pp. 93-101.

Odjugo, P.A.O.., (2010). Regional evidence of climate change in Nigeria, Journal of Geography and Regional Planning, 3(6), pp. 142-150.

OECD (Organisation for Economic Co-operation and Development), (2008). A Comprehensive Annual Report on OECD Activities in 2007-2008, 118p.

Ogbo, A. and Onyedinma, A., (2012). Climate Change Adaptation in Nigeria: Problems and prospects, Sacha Journal of Environmental Studies, 2(1), pp.130-145.

Ogbuabor, E.J., and Egwuchuku, I.E., (2017). The impact of climate change on the Nigerian Economy, International Journal of Energy Economics and Policy, 7(2), pp. 217-223.

Ogundebi, A., (2004). Socio-Economic impacts of flooding in Lagos State, Environmental Impact Anal, 12(1) pp. 16-30.

Okolie, C. A., Ossai, N. O. and Eze, C., (2013). Mitigation of, and adaptation to climate change in the 21st century, International Journal of Research in Arts and Social Sciences, 6(1), pp. 47-59.

Oladipo, E., (1995). An indication of an abrupt change of rainfall and its potential impact on energy development in Nigeria: In Umolu, J.C. (ed.), Global Climate Change: Impact on energy development, DAMTECH Nigeria Limited.

Oladipo, E., (2010). Towards enhancing the adaptive capacity of Nigeria, A review of the country's state of preparedness for climate change adaptation, Report to Heinrich Boll Foundation, Lagos, Nigeria.

Olaniyi, O.A., Fumilayo, O.A. and Olutimehin, I.O., (2014). Review of climate change and its effect on Nigeria ecosystems, International Journal of Environment and Pollution Research, 2(3), pp. $70-81$ 
Olmos, S., (2001). Vulnerability and Adaptation to climate change: Concepts, Issues, Assessment Methods, Climate Change Knowledge Network Foundation Paper, www.cckn.net, pp.1-21.

Olusola, A., (2012). Climate change and the environment: Issues and geoinformation challenges, FIG Working Week, Rome, Italy, $6^{\text {th }}-10^{\text {th }}$ May, 2012.

Onofeghara, L.A., (1995). Nigerian Wetlands, Impacts of global climate change and sea level rise on coastal resources and energy development in Nigeria (DAMTECH NIGERIA LTD).

Onuoha, B.C., (2012). Business and Entrepreneurial Environments, A Nigerian Perspective, African Entrepreneurship Initiative, Port-Harcourt.

Onyenechere, E. and Igbozurike, U., (2008). Women Crop Farmers' adaptation to rainfall variability and climate change in Amaraku community, Imo state, Nigeria, In: Nwajiuba, C. (Ed.): Climate Change and Adaptation in Nigeria, Weikersheim, Germany, Margraf Publishers, pp. 65-72.

Onyenechere, E.C., (2010). Climate Change and Spatial planning concerns in Nigeria: Remedial measures for more effective response, Journal of Human Ecology, 32(3), pp. 137-148.

Onyenechere, E.C., (2011).The Informal Sector and the Environment in Nigerian Towns: "What we Know and What we Still Need to Know", Research Journal of Environmental and Earth Sciences, 3 (1), pp. 61-69.

Osman-Elasha, B., (2010). Climate change adaptation: Options and good practices for the Arab region, Available at: http://www.arabclimateinitiative.org/knowledge/background./CC.Adaptation.pdf (accessed May 10, 2019).

Ozor, N., (2009). Understanding climate change, Implications for Nigerian Agriculture, Policy and Extension, Paper presented at the National Conference on climate change and the Nigeria environment, Organised by the Department of Geography, University of Nigeria, Nsukka, $29^{\text {th }}$ June$2^{\text {nd }}$ July, 2009.

Porter, G. and Brown, J.W., (1991). Global environmental politics: Dilemmas in world politics: Dilemmas in World Politics, San Francisco, Westview Press, 207p.

Raheem, U.A., (2011). Climate Change Related Disasters and Vulnerability: An Appraisal of the Nigerian Policy Environment, Environmental Research Journal, 5(3), pp. 97-103.

Reigart, J.R. and Roberts, J.R., (2013). Recognition and Management of Pesticide Poisonings, $6^{\text {th }}$ Edition, US Environmental Protection Agency, Office of Pesticide Programs, Pennsylvanian Avenue, NW Washington, DC.

SACAU (Southern African Confederation of Agricultural Unions), (2009). Report on: Southern African Regional Workshop on strengthening the Capacity of Farmers' Organisations to respond to changing Agriculture Markets, $2^{\text {nd }}$ to $5^{\text {th }}$ December, 2008, Johannesburg, South Africa.

Satterthwaite, D., Huq, S., Pelling, M., Reid, H. and Lankao, P., (2007). Adapting to climate change in Urban Areas, The possibilities and constraints in low and middle income nations, IIED Working Paper, IIED, London.

Shamar, S. and Kumar, K., (1998). Impacts and vulnerabilities, In: Climate change, Post-Kyoto Perspectives from the South, Tata Energy Research Institute, New Delhi, pp. 61-78.

Slobodan, P., (2012). Floods in a changing climate, Risk Management, Cambridge University Press.

Thomson, M., Connor, S., Ward, N. and Molyneux, D., (2004). Impact of climate vulnerability on infectious diseases in West Africa, Ecological Health, 1(2), pp. 138-150.

Umoh, E., (2007). Flooding problems in Rivers State, Journal of Environmental science, 4(2), pp. 4460. 
UNDP (United Nations Development Programme), (2008). Adaptation to climate change: The New challenge for the development in the developing world, New York, UNDP.

UNDP (United Nations Development Programme), (2013). Overview of Linkages between Gender and Climate Change, New York: UNDP.

UNFCC, (2006). Climate Change: Impacts, Vulnerabilities, and Adaptation in Developing Countries, UNFCC.

US EPA (U.S. Environmental Protection Agency) (2009a). Particulate Matter National Ambient Air Quality Standards: Scope and Methods Plan for Health Risk and Exposure Assessment. U.S. Environmental Protection Agency, Research Triangle Park, NC, February 2009.

US EPA (U.S. Environmental Protection Agency) (2009b). Integrated Science Assessment for Particulate Matter (Final Report), U.S. Environmental Protection Agency, Washington, DC, December 2009.

Uyigue, E. and Agho, M., (2007). Coping with climate change and environmental degradation in the Niger Delta of Southern Nigeria, Community Research and Development Centre, Nigeria (CREDC).

Uyigue, E., Ediang, O. and Ediang, A., (2010). Combating Climate Change: The Role of Renewable Energy and Energy Efficiency, Iranian Journal of Earth Sciences, 2, pp. 150-157.

Watson, R., Zinyoera, M., and Moss, R., (1998). The Regional Impacts of Climate Change: An Assessment of Vulnerability, A Special Report of IPCC Working Group II, Cambridge University Press, Cambridge.

\section{Cite this article as:}

Ikumbur B. and Iornumbe S., 2019. The Impacts of Climate Change on Nigerian Ecosystems: A Review. Nigerian Journal of Environmental Sciences and Technology, 3(2), pp. 268-291. https://doi.org/10.36263/nijest.2019.02.0128 